\title{
Natural killer (NK) cell activity of peripheral blood, synovial fluid, and synovial tissue lymphocytes from patients with rheumatoid arthritis and juvenile rheumatoid arthritis
}

\author{
J. H. DOBLOUG, Ø. FøRRE, T. K. KVIEN, T. EGELAND, AND M. DEGRÉ
}

From the Institute of Immunology and Rheumatology, Oslo Sanitetsforening Rheumatism Hospital, and Wilhelmsens Institute of Bacteriology, Rikshospitalet, the National Hospital, Oslo, Norway

SUMMARY Natural killer (NK) cell activity was investigated in peripheral blood, synovial fluid, and synovial tissue lymphocytes from patients with rheumatoid arthritis (RA) and juvenile rheumatoid arthritis (JRA). Unfractionated lymphocytes, T lymphocytes, and non-T lymphocytes from the 3 compartments of JRA patients had reduced activity compared with that of normal peripheral blood lymphocytes (with p values usually between $0 \cdot 05$ and $0 \cdot 1$ ). Unfractionated synovial tissue lymphocytes of RA patients also showed reduced cytotoxicity $(0 \cdot 05<\mathrm{p}<0 \cdot 1)$, whereas peripheral blood lymphocytes exerted normal NK cell activity. The NK activity was exerted by cells both with and without Fc $\gamma$ receptors. The highest cytotoxicity was observed in Fc $\gamma$ receptor-positive cells, both in peripheral blood and synovial fluid, since more than $70 \%$ reduction in NK activity was found after depletion of Fcy receptor-positive cells. No evidence of lymphocytotoxic antibodies or other factors with influence on NK cells was observed in the patients' sera.

NK cells are important for the surveillance of cancer cell growth and possibly also for protection against viral infections. ${ }^{1-3}$ Little is known, however, about other possible functions of the NK cells, for instance, their contribution to tissue damage in autoimmune diseases. An immunodeficiency disorder involving a selective defect in NK cells has been described, ${ }^{4}$ but whether there exist disease states with NK cell abnormalities restricted to certain lymphocyte populations or subpopulations is not known.

In the mouse the NK cells bear a unique surface antigen, the Ly 5 antigen. ${ }^{5}$ In man these cells seem to be heterogeneous with respect to surface markers, and the activity is exerted by both $\mathrm{T}$ and non- $\mathrm{T}$ lymphocytes, with and without Fcy receptors. ${ }^{67}$

In addition to genetic predispositions and autoimmune mechanisms the possibility also exists that viral infections may play a role in the pathogenesis of rheumatoid arthritis (RA) and juvenile rheumatoid arthritis (JRA). ${ }^{89}$ Such viral infections could be due to a defective antiviral immunity, reflected in

Accepted for publication 24 August 1981.

Correspondence to Dr J. H. Dobloug, Institute of Immunology and Rheumatology, Rikshospitalet University Hospital, F. Quams gate 1 , Oslo 1, Norway. derangements in NK cell activity and in interferon levels. ${ }^{135}$

In this study we have investigated the NK cell activity of peripheral blood, synovial fluid, and synovial tissue lymphocytes from RA and JRA patients. The relation between NK cells and Fc $\gamma$ receptorbearing cells was studied, and we have also looked for a possible association between NK cell activity and interferon titres.

\section{Materials and methods}

Patients. Eight adult patients with classical or definite RA according to the ARA criteria ${ }^{10}$ and 13 patients with JRA according to the criteria of Brewer et al. ${ }^{11}$ were studied. The age distribution in the RA group ranged from 37 to 67 years (mean 47 years) and in the JRA group from 9 to 17 years (mean 12 years). Seven $(88 \%)$ of the RA patients and $2(15 \%)$ of the JRA patients were seropositive and $3(38 \%)$ of the adult patients and $3(23 \%)$ of the children were positive for antinuclear antibodies (ANA positive).

Of the JRA patients, $2(15 \%)$ had the systemic onset type of the disease, $8(62 \%)$ had the pauciarticular type, and $3(23 \%)$ had polyarticular type. ${ }^{11}$ 
Two $(25 \%)$ of the RA patients and one $(8 \%)$ of the JRA patients were receiving long-term steroid treatment. Two JRA patients were on cytostatic drugs (chlorambucil and azathioprine), whereas 3 JRA patients were not on drug treatment. All the other patients were treated with various antiinflammatory drugs in conventional doses.

Effector cells. Peripheral blood mononuclear cells (PB-MNC) were isolated from heparinised blood by Isopaque-Ficoll gradient centrifugation. ${ }^{12}$ The patient's blood was taken at the time of synovial fluid aspiration or on the first day after synovectomy. Synovial fluids were drawn aseptically from knee joints or wrists into heparinised tubes, and the synovial fluid lymphocytes were isolated as described elsewhere. ${ }^{13}$ Only synovial fluid specimens containing $>95 \%$ MNC after Isopaque-Ficoll centrifugation were used. Synovial tissues were obtained by synovectomy in temporary ischaemia under general or local anaesthesia from 8 RA patients and 3 JRA patients. The synovial tissue MNC were eluted according to Abrahamsen et al. ${ }^{14}$ Cells with an appearance similar to PB-MNC constituted approximately $70 \%$ of all the eluted cells, and the viability always exceeded $80 \%$ as judged by trypan blue exclusion.

$\mathrm{T}$ lymphocytes were isolated as previously described. ${ }^{15}$

Target cells. The myeloblastoid cell line K-562 was maintained in continuous suspension culture in complete medium. $1 \times 10^{6}$ cells suspended in $0.3 \mathrm{ml}$ fetal calf serum (FCS) were labelled with $300 \mu \mathrm{Ci}{ }^{51} \mathrm{Cr}$ (Amersham Radiochemicals, England) for $2 \mathrm{~h}$ to achieve approximately $2 \mathrm{cpm} / \mathrm{cell}$. The cells were then washed 3 times in phosphate buffered saline (PBS) supplemented with $5 \% \mathrm{FCS}$, and resuspended to a concentration of $2 \times 10^{4} \mathrm{cells} / \mathrm{ml}$ in Roswell Park Memorial Institute solution (RPMI) $1640+20 \%$ FCS.

Cytotoxicity assay. $0 \cdot 1 \mathrm{ml}$ of effector cells $\left(2 \times 10^{6}\right.$ cells $/ \mathrm{ml}$ ) (unfractionated, $\mathrm{T}$ or non-T lymphocytes) were mixed with $0.1 \mathrm{ml}$ of target cells $\left(2 \times 10^{4}\right.$ cells $/ \mathrm{ml}$ ) in V-bottom microtitre plates (Costar, Cambridge, Mass), centrifuged at $50 \mathrm{~g}$ and $20^{\circ} \mathrm{C}$ for $5 \mathrm{~min}$, and incubated at $37^{\circ} \mathrm{C}$ in $5 \% \mathrm{CO}_{2}$ and $100 \%$ humidity. After incubation for $4 \mathrm{~h}$ the supernatants were collected by a microplate technique ${ }^{16}$ and the radioactivity was counted in a gamma counter. The cytotoxicity index (CI) was calculated according to the formula

$$
\mathrm{CI}(\%)=\frac{\mathrm{C} \exp -\mathrm{C} \text { background }}{\mathrm{C} \text { total }-\mathrm{C} \text { background }} \times 100
$$

where $C$ exp and $C$ background denote counts released into the supernatants in the presence or absence of effector cells respectively, and $C$ total denotes counts in $0 \cdot 1 \mathrm{ml}$ of ${ }^{51} \mathrm{Cr}$ labelled target cells.

Depletion of Fcy receptor bearing cells and blocking of Fcy receptors. Detection and removal of $\mathrm{Fc} \gamma$ receptor-bearing cells was performed with human $\mathrm{O}, \mathrm{Rh}+$ erythrocytes sensitised with anti-Rh Ripley antibodies..$^{17}{ }^{17}$ Furthermore, heat-aggregated $\left(63^{\circ} \mathrm{C}\right.$, $15 \mathrm{~min}$ ) pooled human IgG was added directly to the wells containing effector and target cells at a final concentration of $0.05,0.5$ and $5 \mathrm{mg} / \mathrm{ml}$, and the NK activity was observed.

Treatment of normal lymphocytes with sera from JRA patients. Sera from 4 JRA patients with the lowest peripheral blood NK cell activity were tested for the occurrence of lymphocytotoxic antibodies (anti-NK-cell antibodies). $2 \times 10^{6}$ normal peripheral blood lymphocytes were resuspended in $0.1 \mathrm{ml}$ of heat-inactivated JRA patient serum, and $0.3 \mathrm{ml}$ of human $\mathrm{AB}$ serum was added as complement source. ${ }^{18}$ The mixtures were incubated at $15^{\circ} \mathrm{C}$ for 30 min. The treated cells were then washed 3 times in complete medium, and afterwards adjusted to $2 \times$ $10^{6}$ viable cells $/ \mathrm{ml}$, and used as effector cells in the NK cytotoxicity assay.

Determination of interferon in patient sera. Interferon (IFN) titres were assayed by an infectivity inhibition microtest in human embryonal fibroblast cells with vesicular stomatitis virus as challenge virus according to methods described elsewhere. ${ }^{19}$

Statistics. The results are given as mean values \pm standard error of the mean (SEM). The significance of the observed differences were calculated by using the Mann-Whitney U test. Probability values less than 0.05 2-sided were considered significant, whereas $0 \cdot 05<\mathrm{p}<0 \cdot 1$ was considered as being of low significance.

\section{Results}

NK cell activity in peripheral blood, synovial fluid, and synovial tissue lymphocytes from patients with $R A$ and JRA. The mean cytotoxic indices of peripheral blood, synovial fluid, and synovial tissue lymphocytes of JRA patients are given in table 1 . Reduced NK activity was observed in T lymphocytes from both peripheral blood and synovial fluid as well as in non-T lymphocytes from peripheral blood. Non-T lymphocytes from synovial fluid of JRA patients, however, showed an increased activity compared with that of the corresponding fraction in JRA peripheral blood $(26 \cdot 2 \pm 5 \cdot 3 \%$ compared with $10 \cdot 6 \pm 3.0 \% \quad(p<0.05)$ and also compared with normal peripheral blood non-T lymphocytes.

The cytotoxic indices of peripheral blood and synovial tissue lymphocytes of the RA patients are 
Table 1 NK cell activity (CI in percent) of peripheral blood, synovial fluid, and synovial tissue lymphocytes from patients with JRA

\begin{tabular}{|c|c|c|}
\hline Lymphocytes & $J R A$ patients & Controls \\
\hline \multicolumn{3}{|l|}{ Peripheral blood } \\
\hline Unfractionated & $\begin{array}{l}24 \cdot 3 \pm 3 \cdot 2 \dagger \\
n=13^{*}\end{array}$ & $\begin{array}{l}31 \cdot 8 \pm 4 \cdot 0 \\
n=10\end{array}$ \\
\hline $\mathbf{T}$ & $\begin{array}{l}5 \cdot 2 \pm 0 \cdot 8 \S \\
n=9\end{array}$ & $\begin{array}{l}10 \cdot 4 \pm 1 \cdot 9 \\
n=8\end{array}$ \\
\hline Non- $T$ & $\begin{array}{l}10 \cdot 6 \pm 3 \cdot 0 \S \\
n=9\end{array}$ & $\begin{array}{l}18 \cdot 1 \pm 2 \cdot 3 \\
n=8\end{array}$ \\
\hline \multicolumn{3}{|l|}{ Synovial fluid } \\
\hline Unfractionated & $\begin{array}{l}21 \cdot 8 \pm 3 \cdot 6 \ddagger \\
n=10\end{array}$ & - \\
\hline $\mathbf{T}$ & $\begin{array}{l}6 \cdot 4 \pm 1 \cdot 5 \ddagger \\
n=7\end{array}$ & 一 \\
\hline Non-T & $\begin{array}{l}26 \cdot 2 \pm 5 \cdot 3 \dagger \\
n=6\end{array}$ & 一 \\
\hline \multicolumn{3}{|l|}{ Synovial tissue } \\
\hline Unfractionated & $\begin{array}{l}16 \cdot 2 \pm 6 \cdot 7 \ddagger \\
n=3\end{array}$ & - \\
\hline $\mathbf{T}$ & $\begin{array}{l}20 \cdot 0 \\
n=1\end{array}$ & 一 \\
\hline Non- T & $\begin{array}{l}26 \cdot 4 \\
n=1\end{array}$ & 一 \\
\hline
\end{tabular}

*Number of experiments. Levels of significance: $\dagger p>0.1 . \ddagger 0.05<p<0.1$, $\S \mathrm{p}<0.05$ when compared with the corresponding control cell fractions. Normal peripheral blood lymphocytes were used as controls. $\mathrm{CI}=$ cytotoxicity index.

given in Table 2 . Similar NK cell activity was seen in $\mathrm{T}$ and in non- $\mathrm{T}$ lymphocytes from peripheral blood. In one of the RA patients a dissociation in NK cell activity between peripheral blood and synovial tissue non-T lymphocytes was seen $(7 \cdot 3 \%$ versus $15 \cdot 9 \%)$. Both unfractionated $\mathrm{T}$ and non- $\mathrm{T}$ lymphocytes from the synovial tissue of this RA patient exerted much lower activities than the corresponding fractions of the JRA patients $(12.4 \%, 7.9 \%$, and $15.9 \%$ versus $29 \cdot 5 \%, 20 \cdot 0 \%$, and $26 \cdot 4 \%$ respectively).

NK cell activity related to sex, treatment, and clinical parameters. Of the 13 JRA patients the 10 girls had a mean peripheral blood NK activity of $20 \cdot 5 \pm 3,1 \%$ compared with a mean of $37 \cdot 1 \pm 3 \cdot 8 \%$ of the 3 boys $(p<0.05)$. No correlation was found between peripheral blood NK cell activity and disease activity, the use of antirheumatic drugs, immunoglobulin levels, or the occurrence of autoantibodies in the RA

Table 2 NK cell activity (CI in percent) of peripheral blood and synovial tissue lymphocytes from patients with $R A$

\begin{tabular}{lll}
\hline Lymphocytes & $R A$ patients & Controls \\
\hline $\begin{array}{l}\text { Peripheral blood } \\
\text { Unfractionated }\end{array}$ & $32 \cdot 6 \pm 5 \cdot 3 \dagger$ & $35 \cdot 0 \pm 5 \cdot 5$ \\
& $n=8^{*}$ & $n=8$ \\
T & $10 \cdot 5 \pm 2 \cdot 3$ & $8 \cdot 1 \pm 1 \cdot 9$ \\
Non-T & $n=6$ & $n=6$ \\
Synovial tissue & $14 \cdot 1 \pm 2 \cdot 1$ & $18 \cdot 1 \pm 4 \cdot 7$ \\
Unfractionated & $n=5$ & $n=5$ \\
& $23 \cdot 8 \pm 5 \cdot 6 \ddagger$ & - \\
T & $n=7$ & \\
Non-T & $7 \cdot 9$ & - \\
& $n=1$ & - \\
& $15 \cdot 9$ & \\
\hline
\end{tabular}

For symbols see Table 1 . and JRA patient sera. Neither was there any association between NK cell activity and the lymphocyte count in the synovial fluid.

The role of $F c \gamma$ receptor bearing cells from peripheral blood and synovial fluid as effector cells in the NK cytotoxicity assay. The percentages of $\mathrm{T} \gamma$ cells in peripheral blood, synovial fluid, and synovial tissue lymphocytes of the RA and JRA patients are given in Table 3. In 4 experiments Fcy receptorbearing cells were removed by erythrocyte-antibody rosette-forming cells (EA-RFC) depletion from peripheral blood and synovial fluid $\mathrm{T}$ lymphocytes and from peripheral blood non-T lymphocytes. After depletion of $\mathrm{T} \gamma$ cells normal peripheral blood $\mathrm{T}$ cell cytotoxicity was reduced by $69 \cdot 3 \pm 6 \cdot 4 \%$ (Table 4 ). JRA synovial fluid $T$ cell cytotoxicity was reduced by $26 \cdot 5 \pm 10 \cdot 2 \%$. The cytotoxicity of normal peripheral blood non- $T$ lymphocytes was reduced by $73 \cdot 4 \pm 5 \cdot 4 \%$ following depletion of EA-RFC.

To elucidate whether NK cell activity is dependent on intact (unblocked) Fcy receptors on the effector cells or not aggregated IgG was added to the assay in varying concentrations. Inhibition was observed of all cell fractions tested from both peripheral blood and synovial fluid, and a significant inhibition was observed with IgG concentrations between 0.05 and $0.5 \mathrm{mg} / \mathrm{ml}$ (data not shown).

Table 3 Percentage T $\gamma$ cells in peripheral blood, synovial fluid, and synovial tissue lymphocytes of patients with $R A$ and JRA

\begin{tabular}{llll}
\hline Lymphocytes from & RA patients & JRA patients & Controls \\
\hline Peripheral blood & $13 \cdot 1 \pm 2 \cdot 0$ & $8 \cdot 4 \pm 1 \cdot 2$ & $13 \cdot 6 \pm 1 \cdot 3$ \\
& $n=8^{*}$ & $n=13$ & $n=30$ \\
Synovial fluid & $\mathrm{NT}$ & $11 \cdot 6 \pm 1 \cdot 5$ & $\mathrm{NT}$ \\
& & $\mathrm{n}=7$ & \\
Synovial tissue & $15 \cdot 5 \pm 3 \cdot 9$ & $8 \cdot 0 \pm 7 \cdot 1$ & $\mathrm{NT}$ \\
& $\mathrm{n}=4$ & $\mathrm{n}=2$ & \\
\hline
\end{tabular}

*Number of experiments. NT= not tested owing to lack of material.

Table 4 NK cell activity (CI in per cent) in normal peripheral blood and JRA synovial fluid lymphocytes before and after depletion of $F c \gamma$ receptor bearing cells (EA-RFC)

\begin{tabular}{lrc}
\hline Cells tested & $C I$ & \multicolumn{1}{l}{$\begin{array}{l}\text { CI after depletion of } \\
\text { EA-RFC }\end{array}$} \\
\hline $\begin{array}{l}\text { Normal peripheral blood lymphocytes } \\
\text { Unfractionated }\end{array}$ & \\
T & $47 \cdot 1 \pm 6 \cdot 8$ & $11 \cdot 4 \pm 1 \cdot 0(76 \cdot 2 \pm 4 \cdot 5)^{*}$ \\
Non-T & $17 \cdot 7 \pm 3 \cdot 4$ & $5 \cdot 0 \pm 0 \cdot 7(69 \cdot 3 \pm 6 \cdot 4)$ \\
JRA synovial fluid lymphocytes & $5 \cdot 9 \pm 0 \cdot 2(73 \cdot 4 \pm 5 \cdot 4)$ \\
Unfractionated & $23 \cdot 8 \pm 8 \cdot 7$ & $6 \cdot 7 \pm 1 \cdot 6(71 \cdot 8 \pm 5 \cdot 1)$ \\
$T$ & $8 \cdot 7 \pm 0 \cdot 8$ & $6 \cdot 4 \pm 1 \cdot 2(26 \cdot 5 \pm 10 \cdot 2)$ \\
\hline
\end{tabular}

${ }^{*}$ Per cent reduction in NK cell activity.

The numbersrepresent mean $\% \pm$ SEM of 4 separate experiments. Due to the low number of non-T lymphocytes in synovial fluid mononuclear cells, EA-RFC depletion from these cell fractions could not be performed. After depletion less than $0.5 \%$ rosette forming cells ( $\mathrm{T} \gamma$ cells) was left in the $\mathrm{T}$ cell fractions and less than $3.0 \%$ in the non-T cells. 
NK cell activity of normal peripheral blood lymphocytes treated with JRA patient's sera and complement. Normal peripheral blood lymphocytes were treated with sera from the $4 \mathrm{JRA}$ patients with lowest NK cell activities (mean CI of these 4 patients was $12 \cdot 5 \pm 1 \cdot 8 \%)$. No alteration in NK cell activity or in cell viability was observed after the treatment (data not shown).

Relation between $N K$ cell activity and serum interferon (IFN) levels. Total IFN levels were determined in the sera of the $8 \mathrm{RA}$ and of $8 \mathrm{JRA}$ patients. No significant differences were observed between the RA and the JRA patient groups (mean titres of $12 \cdot 0 \pm 1 \cdot 1$ and $11 \cdot 3 \pm 0 \cdot 6$ in the RA and the JRA group respectively) nor between the patient groups and the controls. Significant IFN titres were detected in $3 \mathrm{RA}$ and 4 JRA patients, and further specificity testing indicated that the activity was due to immune $(\gamma)$ IFN. No association between high titres of immune $(\gamma)$ IFN and high NK cell activity was seen, since high IFN levels were observed in RA and JRA patients with both high and low NK cell activity.

\section{Discussion}

In this study we found reduced NK cell activity in peripheral blood, synovial fluid, and synovial tissue lymphocytes of JRA patients. In contrast only a slightly reduced spontaneous cytotoxicity was seen in the peripheral blood of RA patients, whereas RA synovial tissue lymphocytes also showed reduced cytotoxicity. Thus a local reduction in NK activity compared to peripheral blood lymphocytes from healthy individuals ( $p$ values usually between 0.05 and $0 \cdot 1$ ) seems to be a constant feature of both RA and JRA patients. However, there was a large individual variation of NK activity in the JRA and RA lymphocyte experiments from the various compartments. The reduced cytotoxicity could be due to blocking of NK cell Fcy receptors by immune complexes. ${ }^{20}$ The reduction could also reflect low interferon concentrations, as NK cells are activated by this substance. ${ }^{5}$ However, no association between serum interferon titres and peripheral blood NK cell activity was observed either in the patient groups or in individual patients.

It is currently believed that NK cells play an important role in preventing the development of cancer. ${ }^{23}$ They may also participate in the defence against viral infections. ${ }^{1}$ Thus decreased NK cell activity has been observed in patients with certain malignant and premalignant diseases ${ }^{22}$ as well as in a few other disease states. ${ }^{48}$ There is to our knowledge no increased frequency of malignant diseases among RA and JRA patients, but these patients frequently have antiviral antibodies in their sera and also antiviral antibody- producing cells in the synovial tissue. ${ }^{23}$ Local impairment of cellular immunity to viral antigens has also been demonstrated in these groups of patients. $^{24}{ }^{25}$ The reduced NK cell activity now observed could permit virus to persist and replicate in the organism, for example, locally in the synovial tissue, thus leading to prolonged stimulation of the immune system. Chronic viral infections might therefore participate in the pathogenesis of these diseases.

The NK cell activity and the percentage $\mathrm{T} \gamma$ cells were both reduced in the peripheral blood, synovial fluid, and synovial tissue lymphocytes of the JRA patients, whereas both were normal in the peripheral blood of the RA patients. However, in synovial tissue of RA patients the percentage T $\gamma$ cells was increased, whereas the NK cell activity was reduced. This discrepancy between membrane markers and cell function may in part be explained by a local expansion of Fcy receptor-bearing cells without NK activity, for example, due to local activation. Proliferation of Fcy receptor-bearing cells is also a constant feature after stimulation in vitro. ${ }^{26}$ The high number of HLA DR positive $\mathrm{T}$ lymphocytes, ${ }^{27}$ the high spontaneous uptake of ${ }^{3} \mathrm{H}$-thymidine ${ }^{28}$ together with the high percentage of plasma cells in synovial tissue ${ }^{29}$ also strongly indicate local activation.

Evidence of lymphocytotoxic antibodies with specificity for NK cells was not obtained either in the JRA or in the RA patient sera. Antilymphocytic antibodies have been demonstrated in JRA patients with suppressor cell defects. ${ }^{29}$ Neither were other factors with influence on NK cell activity detected in the patient sera.

Jan H. Dobloug is a research fellow sponsored by the Norwegian Hydro Company. The synovial tissue specimens used in this study were kindly provided by Dr Jan Pahle, head of the Surgical Department, Oslo Sanitetsforening Rheumatism Hospital. The skilful technical assistance of Bodil Lunden and Margaretha Wikholm Kabbe is gratefully acknowledged, and we are indebted to Sissel Bergersen for benevolent secretarial assistance. We also thank $\mathrm{Dr}$ Ove J. Mellbye for valuable discussions on the manuscript.

\section{References}

\footnotetext{
1 Andersson T, Stejskal V, Härfast B. An in vitro method for study of human lymphocyte cytotoxicity against mumps virus infected target cells. J Immunol 1975; 114: 237-43.

${ }^{2}$ Haller $\mathrm{O}$, Hansson M, Kiessling R, Wigzell H. Role of nonconventional natural killer cells in resistance against syngeneic tumour cells in vivo. Nature 1977; 270: 609-11.

3 Welsh R M Jr. Opinion. Mouse natural killer cells: induction specificity, and function. $J$ Immunol 1978; 121: 1631-5.

4 Roder J C, Haliotis T, Klein M, et al. A new immunodeficiency disorder in humans involving NK cells. Nature 1980; 284: 553-5.

5 Minato N, Reid L, Cantor H, Lengyel P, Bloom B R. Mode of regulation of natural killer cell activity by interferon. J Exp Med 1980; 152: 124-37.

${ }^{6}$ Jensen P J, Koren H S. Heterogeneity within the population of NK and K cells. J Immunol 1980; 124: 395-8.
} 
7 Neville M E. Human killer cells and natural killer cells: Distinct subpopulations of Fc receptor-bearing lymphocytes. J Immunol 1980; 125: 2604-9.

8 Fudenberg H. Molecular theology, immunophilosophy, and autoimmune disease. Scand J Immunol 1980; 12: 459-65.

9 Bennett J C. The infectious etiology of rheumatoid arthritis. New considerations. Arthritis Rheum 1978; 21: 531-8.

10 Ropes M W, Bennet G A, Cobb S, Jacox R, Jessar R A. 1958 revision of diagnostic criteria for rheumatoid arthritis. Bull Rheum Dis 1958; 9: 175-6.

11 Brewer E J Jr, Bass J, Baum J, et al. Current proposed revision of JRA criteria. Arthritis Rheum 1977; 20: 195-9.

12 Bøyum A. Isolation of lymphocytes, granulocytes and macrophages. Scand J Immunol 1976; 5: suppl 5, 9-15.

${ }^{13}$ Frøland S S, Natvig J B, Husby G. Immunological characterization of lymphocytes in synovial fluid from patients with rheumatoid arthritis. Scand J Immunol 1973; 2: 67-73.

${ }_{14}$ Abrahamsen T G, Frøland S S, Natvig J B, Pahle J. Elution and characterization of lymphocytes from rheumatoid inflammatory tissue. Scand J Immunol 1975; 4: 823-30.

15 Dobloug J H, Førre Ø, Lea T, Solheim B G, Natvig J B. Detection of Fc-receptor-bearing human lymphocytes. The majority of T $\mu$ cells carry HLA-DR antigens. Clin Immunol Immunopathol 1981; 19: 224-37.

${ }^{16}$ Hirschberg H, Skare H, Thorsby E. Cell mediated lympholysis: CML a microplate technique requiring few target cells and employing a new method of supernatant collection. J Imunol Methods 1977; 2: 131-41.

${ }^{17}$ Frøland S S, Natvig J B. Identification of three different human lymphocyte populations by surface markers. Transplant Rev 1973; 16: 114-62.

${ }^{18}$ Goto $M$, Tanimoto $\mathrm{K}$, Horiuchi $\mathrm{Y}$. Natural cell mediated cytotoxicity in systemic lupus erythematosus: suppression by antilymphocyte antibody. Arthritis Rheum 1980; 23: 1274-81.

19 Dahl H, Degré M. A micro assay for mouse and human interferon. Acta Pathol Microbiol Scand (B) 1972; 80: 863-70.

${ }_{20}$ Munthe E, Natvig J B. Immunoglobulin classes, subclasses and complexes of IgG rheumatoid factor in rheumatoid plasma cells. Clin Exp Immunol 1972; 12: 55-70.

${ }^{21}$ Winchester R J, Agnello V, Kunkel H G. Gamma globulin complexes in synovial fluids of patients with rheumatoid arthritis. Partial characterization and relationship to lowered complement levels. Clin Exp Immunol 1970; 6: 689-706.

22 Auer I O, Ziemer E, Sommer H. Immune status in Crohn's disease. V. Decreased in vitro natural killer cell activity in peripheral blood. Clin Exp Immunol 1980; 42: 41-9.

${ }^{23}$ Chattopadhyay H, Chattopadhyay C, Natvig J B, Wiger D, Mellbye $O$ J. Demonstration of anti-rubella antibody secreting cells in rheumatoid arthritis patients. Scand J Immunol 1979; 10: $47-54$.

24 Anders E M, Natvig J B. Cell mediated immunity to viruses measured by the indirect agarose technique of leukocyte migration inhibition. Cell Immunol 1976; 27: 214-29.

${ }^{25}$ Chattopadhyay H, Chattopadhyay C, Natvig J B. Hyporesponsiveness to virus antigens in rheumatoid synovial and blood lymphocytes using the indirect leukocyte migration inhibition test. Scand J Immunol 1979; 10: 585-92.

${ }^{26}$ Dobloug J H, Førre $\emptyset$, Chattopadhyay C, Natvig J B. Concanavalin A induces suppressor cell activity both in $\mathrm{T} \gamma$ and Tnon- $\gamma$ cells. The majority of the suppressor cells does not carry HLA DR antigens. In press.

${ }^{27}$ Førre $\emptyset$, Dobloug J H, Natvig J B. Augmented numbers of HLA DR positive $T$ lymphocytes in the synovial fluid and the synovial tissue of patients with rheumatoid arthritis and juvenile rheumatoid arthritis. In-vivo activated $T$ lymphocytes are potent stimulators in the mixed lymphocyte reaction (MLR). Scand $J$ Immunol in press.

${ }^{28}$ Abrahamsen T G, Frøland S S, Natvig J B, Pahle J. Antigen and unspecific mitogen stimulation of lymphocytes eluted from rheumatoid inflammatory tissue. Scand J Immunol 1976; 5: $1057-63$.

29 Strelkauskas A J, Callery R T, McDowell J, Borel Y, Schlossman, S F. Direct evidence for loss of human suppressor cells during active autoimmune disease. Proc Natl Acad Sci USA 1978; 75: $5150-4$. 